\title{
Biochemical Composition and Glucose Syrup Production Potential of Elite Yam Varieties from Benue State, Nigeria
}

\author{
Nwankwo P01* and Ukpabi JU2 \\ ${ }^{1}$ National Root Crops Research Institute, Nigeria \\ ${ }^{2}$ National Root Crops Research Institute Umudike, CEFTER, Benue State University, \\ Nigeria
}

\section{Research article \\ Volume 3 Issue 5}

Received Date: November 09, 2018

Published Date: November 28, 2018

DOI: $10.23880 /$ ijbp-16000142

*Corresponding author: Patience Nwankwo, National Root Crops Research Institute, Umudike. Abia State, Nigeria, Tel: 8033853537; Email: pastornwankwo@yahoo.com

\section{Abstract}

The starchy tubers of five elite white yam (Dioscorea rotundata) varieties (Okpani, Hemba, Ogoja, Dorban and Ameh) from Benue State (North - Central, Nigeria) were biochemically assessed as possible raw materials for the production of glucose syrup and yam flour. Glucoamylase enzyme was used in profiling the rate of glucose production. The glucose production was monitored using the glucose oxidase method. Standard phytochemical methods were used to determine the proximate composition and mineral content of the samples. Results showed that the gelatinized starch slurry of Okpani variety gave the highest rate of glucose syrup production $(60 \%)$ at 24 hours reaction time followed equally by those of Hemba and Ameh (55\%) respectively. The five elite yam varieties had a pre-processing proximate composition of $3.01-3.81 \%$ protein, $0.81-1.03 \%$ fat, $1.46-1.74 \%$ crude fibre, $1.29-1.31 \%$ ash and $47.41-48.78 \%$ moisture. The calculated caloric values and total carbohydrate were (198.15 - $203.62 \mathrm{Cal} / 100 \mathrm{~g})$ and $(43.99-45.13 \%)$. The mineral analyses showed that the yam varieties had appreciable values for mineral elements such as $0.36-0.57 \mathrm{mg} / 100 \mathrm{~g}$ phosphorus, $0.30-0.70 \mathrm{mg} / 100 \mathrm{~g}$ potassium, $0.07-1.20 \mathrm{mg} / 100 \mathrm{~g}$ calcium, $0.38-0.47 \mathrm{mg} / 100 \mathrm{~g}$ magnesium, $0.02-$ $0.05 \mathrm{mg} / 100 \mathrm{~g}$ iron, $0.05-0.07 \mathrm{mg} / 100 \mathrm{~g}$ sodium and $0.01-0.03 \mathrm{mg} / 100 \mathrm{~g}$ zinc. The futuristic potentials of the obtained values were discussed in the paper.

Keywords: Dioscorea rotundata; Glucoamylase; Glucose Syrup; Biochemical Analyses

\section{Introduction}

Nigeria is presently the largest producer of edible yam with Benue State producing a substantial quantity of the national output. The indigenes of Benue State are also noted to consume the crop mainly as pounded yam (yam fufu) or boiled yam (to a lesser extent) as well as make sales. Though the starchy yam tuber is processed and utilized as yam flour (elubo/alubo) largely in South -West and South - East Nigeria, there is no documented research work on the use of Benue yams for yam flour or other analytical products such as starch and/or sugar syrup. Many industrial products such as modified starches, maltodextrins, high fructose syrup (HFS), glucose syrup, 


\section{International Journal of Biochemistry \& Physiology}

gums, adhesives, bioethanol, etc are made from starch [1]. The industrial processing of starch to sugars can be carried out either by acid or enzyme hydrolysis. Production of glucose syrup by acid hydrolysis however produces variable quality of the syrup due to the difficulty of controlling the reaction [2]. Also the higher dextrose equivalent syrups made by acid hydrolysis tend to have a bitter taste and dark colour due to the production of hydroxymethylfurfural and other products of reversion such as gentiobose, isomaltose and trehalose which give unacceptable flavors to the syrup [3]. Starch pastes of all types are susceptible to hydrolysis by amylolytic enzymes resulting in shorter polymer chain lengths and sharply reduced viscosities and can easily be hydrolyzed to form syrup containing dextrose, maltose and other oligosaccharides [4]. The production of syrups by enzyme method is amongst the most advanced food technologies characterized by higher yields, wide range of products, higher product quality and energy economy [5,3]. With enzymes it is possible to produce syrups with dextrose equivalent from 28 and up to 98. These biological approaches of using enzymes in glucose syrup production has become economically attractive for biotechnological industries and with the increase in demand for sugar both for nutrition and industries, enzyme technology has thus led to a decrease in the high costs of glucose syrup production [6]. Glucose syrup is a concentrated aqueous solution of glucose maltose and other nutritive saccharides from the hydrolysis of edible starch. Glucose syrup is used in large quantities in fruits, liquors, bakery products, pharmaceuticals and brewery products as well as in cosmetics industries. It is used in food to soften texture, add volume, prevent crystallization of sugar and enhance flavor. Its major uses in commercially prepared foods are as thickener, sweetener and humectants [5]. In the absence of yam product diversification, farmers in Benue State may suffer economically if and when there is a heavy glut in the yam market. This study is therefore aimed at biochemically assessing the potential production of glucose syrup and energy rich yam flour from the elite yam varieties of Benue State of Nigeria.

\section{Materials and Methods}

Chemicals: All chemicals were of analytical grade.

Yam Varieties: The yam varieties were originally obtained from Benue State by the yam programme of National Root Crops Research Institute (NRCRI) Umudike, Umuahia. Abia State. Nigeria.

Enzymes: Alpha- amylase was obtained commercially from Sigma Industries Ltd.
Glucoamylase - The production of glucoamylase was carried out by surface culture of Aspergillus niger, isolated from the soil using Sabourand agar supplemented with penicillin.

\section{Isolation of glucoamylase enzyme: Organism, culture and enzyme production.}

Aspergillus niger was isolated from the soil sample and identified according to the method of Polakovic and Bryjak, [7] with slight modifications. One gram (1g) of soil sample taken from the top $20 \mathrm{~cm}$ of the soil was dissolved in $10 \mathrm{ml}$ of distilled water and serial dilutions were transferred to petridishes containing Sabourand agar (glucose $4 \%$, peptone $1 \%$, $^{-C_{S O}}{ }_{4} 0.001 \%$ and agar $1.5 \%$ ) and supplemented with $500 \mathrm{mg} / \mathrm{l}$ of penicillin. After inoculating the soil sample, the culture plates were incubated for 7 days at $30^{\circ} \mathrm{C}$. Then after growth, the fungal species were further isolated by dilution plate and single pore culture method and then subjected to taxonomic studies according to Polakovic and Bryjak [7]. The spores $\left(10^{7} \mathrm{ml}^{-1}\right)$ were transferred to $500 \mathrm{ml}$ of liquid medium consisting of yeast extract $1 \%, \mathrm{MgSO}_{4} .7 \mathrm{H}_{2} \mathrm{O} 1 \%, \mathrm{FeSO}_{4}$, $0.01 \%, \quad \mathrm{CaCl} .2 \mathrm{H}_{2} \mathrm{O}, \quad 0.01 \%, \quad \mathrm{KH}_{2} \mathrm{PO}_{4}, 0.02 \%, \quad\left(\mathrm{NH}_{2}\right) \mathrm{SO}_{4}$, $0.125 \%$ and starch $1 \%$. After incubation under constant shaking (150rpm) for 48 hours at $32^{\circ} \mathrm{C}$, the culture supernatant was collected by filtration through Whatman no. 4 filter paper and kept at $120^{\circ} \mathrm{C}$ until use.

\section{Yam processing}

Yam flour: The production of yam flour was carried out using the procedure of Ukpabi and Uti, [8] with slight modification. Yam flour when properly processed and well packaged can be stored for a period of six months and above.

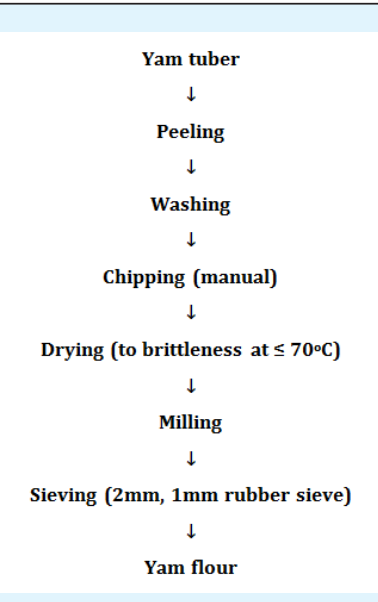

Figure 1: Flow chart for the production of yam flour. 


\section{International Journal of Biochemistry \& Physiology}

\section{Extraction of starch from yam samples:}



Figure 2: Flow-chart for the production of yam tuber starch.

Percentage starch yield $=$ Dry weight of starch recovered from extraction/Dry weight (5g) of yam sample X 100

Proximate composition: Proximate composition (moisture, ash, crude fibre, crude protein and crude fat) of fresh yam samples were determined using the standard method of AOAC, 1990 [9]. Crude protein was expressed as $\%$ nitrogen $\mathrm{x} 6.25$, while carbohydrate content was determined by difference.

Caloric value: The caloric values of the elite yam varieties were obtained using the method of Onyeike, et al. [10]. The crude fat, protein and carbohydrate contents were multiplied by 9,4 and 4 (Atwater factors) respectively. The caloric values were then calculated as the sum of the products and expressed as calories.

Mineral analysis: The mineral composition was determined according to the method described by
Shahidi, et al. [11]. Phosphorus content of the digest was determined colorimetrically according to the method described by Obadoni and Ochuko, 2001[12].

\section{Production of Glucose Syrup}

Glucose syrup production from various starch samples of the elite yam varieties was carried out by the method reported by Ji, et al. [13] with slight modifications. A suspension of $30 \%(\mathrm{w} / \mathrm{v})$ of previously extracted yam starch was prepared. The suspension $\mathrm{pH}$ was adjusted using $0.2 \mathrm{M}$ pH 6.0 phosphate buffer. This suspension was maintained under heating, increasing the temperature in $1{ }^{\circ} \mathrm{C} /$ minute, until the starch was completely solubilized. After it was cooled down, the solution was incubated in water bath at $50^{\circ} \mathrm{C}$ with $10 \mathrm{ml}$ of commercial $\alpha$-amylase Sigma $^{\Phi}(1 \mathrm{mg} / \mathrm{ml})$ for 2 hours for total liquefaction.

For saccharification, this resulting maltodextrin syrup had its $\mathrm{pH}$ adjusted to 4.2 with $0.2 \mathrm{M}$ of acetate buffer. Then $100 \mathrm{ml}$ of previously produced and characterized glucoamylase solution was added and incubated at $60^{\circ} \mathrm{C}$ for 48 hours under constant agitation. The glucose production was monitored using the glucose oxidase method [14]. The resulting syrup was purified by ion exchange chromatography and concentrated by evaporation under reduced pressure.

Statistical analysis: Statistics Analysis System (SAS)/PC software was used for mean separations and standard deviations of data.

\section{Results and Discussions}

The results of the hydrolysis of the gelatinized yam starches with glucoamylase from Aspergillus niger are presented in Figure 3. All selected yam varieties investigated showed optimum starch hydrolysis (glucose syrup production) at 24 hours reaction time. Results showed that the gelatinized starch slurry of Okpani variety gave the highest rate of glucose syrup production $(60 \%)$ at 24 hours reaction time followed equally by Hemba and Ameh (55\%) respectively. The glucose concentration increased remarkably at 24 hours reaction time compared to the values obtained at $4-12$ hours. The results also revealed that after the maximum production of glucose syrup at 24 hours reaction time, there was no remarkable increase in glucose syrup production observed at 36 - 48 hours reaction time. This report is in line with the finding of Zainab, et al. [15] that after the optimum production of glucose syrup using starches from selected cereals, the production of glucose syrup did not 


\section{International Journal of Biochemistry \& Physiology}

increase significantly with increase in reaction time. Okpani which is highly affected by browning reaction and often not the choice variety for consumption was found in this investigation to be good in the production of glucose syrup and rich in nutrient composition thus may be recommended for glucose syrup production to avoid waste and also improve economy.

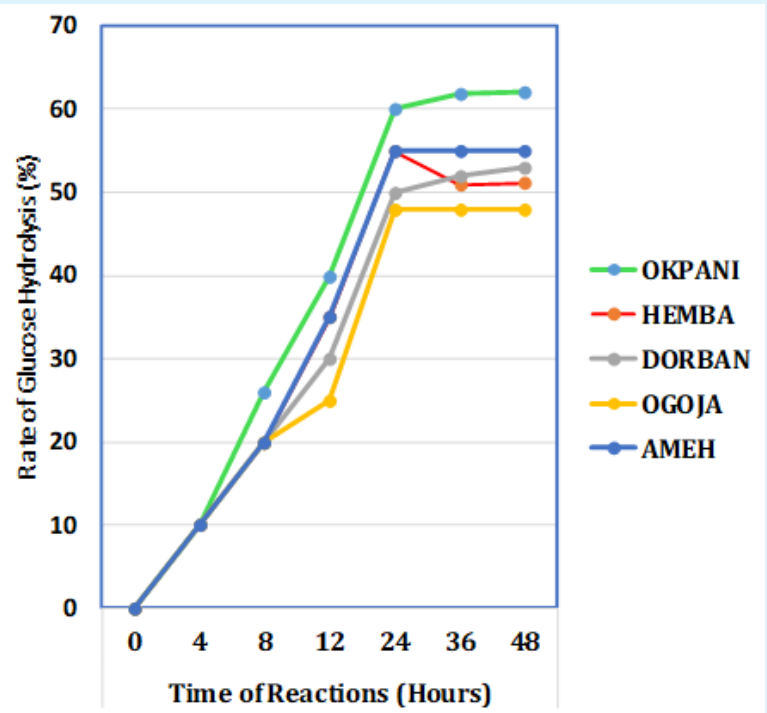

Figure 3: Glucose syrup production from starch of the elite yam varieties.

The proximate analysis is a set of methods used to get information about the nutritional value of food. Thus knowledge of carbohydrate, protein, lipid, fibre and ash content of the food is fundamental to the assessment of its nutritive quality [16]. The results of the analyses of the proximate composition of the selected elite yam varieties are shown in Table 1. The high moisture content of the fresh samples studied is an indication that the yam varieties are prone to microbial attack in the course of storage and at such may not be stored favourably over a long period of time [17]. Low moisture content is desirable for good shelf life, as water in addition to participating in chemical and biochemical reactions involving hydrolysis also serve as a modifier of a catalytic activity of some other substances in foods [18]. Crude protein was moderately high in all samples with Ameh having the highest value. Proteins are polymers of amino acids and are required for the building and repair of damaged tissues [19]. The high fibre content in all samples studied showed that the selected elite yam varieties could be useful as sources of fibre and may play a useful role in providing roughage that aids digestion [20]. Results of previous studies have shown that increase in consumption of fibre has contributed to the reduction in the incidence of certain diseases such as colon cancer and various other disorders [21]. The results of the investigation showed that ash content of all samples were moderately high. The high ash content of the elite yam varieties is an indication of a rich mineral composition, though with wide variations in their elemental mineral constituents [22,23]. Ash is a measure of total mineral content in a sample, a pointer that the samples could be of nutritional importance. All samples had high content of carbohydrate as well as high caloric values, and thus could be used as rich sources of energy [24].

\begin{tabular}{|c|c|c|c|c|c|c|c|}
\hline $\begin{array}{c}\text { Yam } \\
\text { Species }\end{array}$ & Crude Fat & Crude Protein & Crude Fibre & Ash & Moisture & Carbohydrate & $\begin{array}{c}\text { Caloric Values } \\
\text { (Cal/100g) }\end{array}$ \\
\hline Okpani & $1.03 \pm 0.002$ & $3.64 \pm 0.02$ & $1.50 \pm 0.02$ & $1.34 \pm 0.004$ & $47.47 \pm 0.02$ & $44.69 \pm 0.02$ & $202.53 \pm 0.02$ \\
\hline Hemba & $0.89 \pm 0.04$ & $3.76 \pm 0.02$ & $1.47 \pm 0.01$ & $1.37 \pm 0.003$ & $47.41 \pm 0.03$ & $45.14 \pm 0.01$ & $203.62 \pm 0.02$ \\
\hline Ogoja & $0.91 \pm 0.02$ & $3.53 \pm 0.03$ & $1.46 \pm 0.01$ & $1.34 \pm 0.001$ & $48.77 \pm 0.03$ & $43.97 \pm 0.05$ & $198.15 \pm 0.05$ \\
\hline Dorban & $0.90 \pm 0.04$ & $3.01 \pm 0.01$ & $1.55 \pm 0.01$ & $1.29 \pm 0.01$ & $48.68 \pm 0.03$ & $44.58 \pm 0.02$ & $198.46 \pm 0.02$ \\
\hline Ameh & $0.81 \pm 0.01$ & $3.81 \pm 0.02$ & $1.74 \pm 0.001$ & $1.36 \pm 0.002$ & $47.78 \pm 0.02$ & $44.52 \pm 0.03$ & $200.47 \pm 0.02$ \\
\hline
\end{tabular}

Table 1: Proximate composition of yam samples ( $\%$ composition)

Mean of five determinations \pm standard deviation

The results of the mineral composition of the elite yam varieties are shown in Table 2. All samples had high values of potassium, phosphorus, calcium and magnesium. Sodium was not high in all samples studied. Iron and Zinc had relatively appreciable values. The ratio of sodium to potassium $(\mathrm{Na} / \mathrm{K})$ in the body is of great concern for prevention of high blood pressure [25]. $\mathrm{Na} / \mathrm{K}$ ratio less than one is recommended [26]. The ratio of $\mathrm{Na} / \mathrm{K}$ was less than one $(\mathrm{Na} / \mathrm{K}<1)$ in all samples studied, thus the elite yam varieties studied would not promote 


\section{International Journal of Biochemistry \& Physiology}

high blood pressure. These mineral elements are essential for proper cells and when properly combined together

regulate blood pressure.

\begin{tabular}{|c|c|c|c|c|c|c|c|}
\hline $\begin{array}{c}\text { Yam } \\
\text { Species }\end{array}$ & Phosphorous(P) & Potassium(K) & Calcium (Ca) & Magnesium (Mg) & Iron (Fe) & Zinc (Zn) & Sodium (Na) \\
\hline Okpani & $0.55 \pm 0.029$ & $0.70 \pm 0.02$ & $1.20 \pm 0.02$ & $0.47 \pm 0.016$ & $0.05 \pm 0.01$ & $0.03 \pm 0.008$ & $0.07 \pm 0.008$ \\
\hline Hemba & $0.53 \pm 0.02$ & $0.60 \pm 0.02$ & $1.10 \pm 0.02$ & $0.40 \pm 0.016$ & $0.03 \pm 0.01$ & $0.02 \pm 0.008$ & $0.06 \pm 0.003$ \\
\hline Ogoja & $0.48 \pm 0.01$ & $0.42 \pm 0.01$ & $1.15 \pm 0.02$ & $0.40 \pm 0.016$ & $0.03 \pm 0.01$ & $0.01 \pm 0.007$ & $0.06 \pm 0.002$ \\
\hline Dorban & $0.53 \pm 0.01$ & $0.59 \pm 0.02$ & $1.10 \pm 0.01$ & $0.43 \pm 0.01$ & $0.04 \pm 0.01$ & $0.02 \pm 0.003$ & $0.20 \pm 0.399$ \\
\hline Ameh & $0.36 \pm 0.01$ & $0.30 \pm 0.02$ & $0.07 \pm 0.012$ & $0.38 \pm 0.012$ & $0.02 \pm 0.01$ & $0.01 \pm 0.007$ & $0.05 \pm 0.002$ \\
\hline
\end{tabular}

Table 2: Mineral Compostion Of The Yam Flour (Mg/100g Dry Matter).

Mean of five determinations \pm standard deviation

\section{Conclusion and Recommendation}

The technology used for glucose production using the starches from the selected elite yam varieties and enzymes produced by the microorganism Aspergillus niger was successful and can be up-scaled for industrial purposes. There is need for a future study that will involve agricultural economists, agronomists and rural sociologists/extensionists.

\section{References}

1. Johnson R, Padmaja G (2011) Utilization of cassava fibrous residue for the production of glucose and high fructose syrup. Industrial Biotechnol 7(6): 448-455.

2. Aderibigbe FA, Adejumo LA (2015) Effect of different hydrolysis methods on starch degradation. African J Biotechnol 14(3): 264-271.

3. Osemwengie SO, Omorodion SNE (2013) A study of the production of glucose syrup from cassava starch using acid hydrolysis and the preservation using sodium bisulfate. Advanc Mat Res 824: 347-353.

4. Spohner SC, Muller H, Quitmann H, Czermark P (2015) Expression of enzymes for the usage in food and feed industry with Pichia pastoris. J Biotechnology 202: 118-134.

5. Paula MS, Perola OM (2010) Application of microbial $\alpha$ - amylase in industry - A review. Brazilian J Microbiol 41(4): 850-861.

6. Marin-Navarro J, Polaina J (2011) Glucoamylase: structural and biotechnological aspects. Appl Microbiol Biotechnol 89(5): 1267-1273.
7. Polakovic M, Bryjak J (2004) Modeling of potato starch saccharification by an Aspergillus niger glucoamylase. Biochemical Eng J 18(1): 57-63.

8. Ukpabi JU, Oti E (2010) Storage, processing and utilization of yam. In: Yam, cocoyam and sweet potato production and post - harvest management. Ukpabi JU, Nwosu KI (Eds.), NRCRI Umudike, pp: 81-94.

9. AOAC (1990) Official Methods of Analysis, Association of Official Analytical Chemists, Washington D.C.

10. Onyeike EN, Olungwe T, Uwakwe AA (1995) Effect of heat treatment and defatting on the proximate composition of some Nigerian local soup thickeners. Food Chemistry 53(2): 173-175.

11. Shahidi F, Chavan UD, Bal AK, McKenzie DB (1999) Chemical composition of beach pea (Lathyrus maritimus L.) plant parts. Food Chem 64(1): 39-44.

12. Obadoni BO, Ochuko PO (2001) Phytochemical studies and comparative efficacy of the crude extracts of some homeostatic plants in Edo and Delta States of Nigeria. Global J Pure Appl Sci 8(2): 203-208.

13. Ji Y, Seetharaman K, White PJ (2004) Optimizing a small scale corn starch extraction method for use in the laboratory. Cereal Chem 81(1): 55-65.

14. Trevor P (2005) Enzymes: Biochemistry, Biotechnology and Clinical chemistry. $2^{\text {nd }}$ (Edn.), pp: 205-362.

15. Zainab A, Modu S, Falmata AS, Maisaratu U (2011) Laboratory scale production of glucose syrup by the enzymatic hydrolysis of starch made from maize, 


\section{International Journal of Biochemistry \& Physiology}

millet and sorghum. Nigeria Society of Exp Biol 23(1): 1-8.

16. Okaka JC, Akobundu ENT, Okaka ANC (2002) Human Nutrition - An Integrated Approach. 2 ${ }^{\text {nd }}$ (Edn.), OCJANCO Academic Publishers, Enugu.

17. Ezeama CF (2007) Food Microbiology Fundamentals and Applications. Natural Prints, Lagos Nigeria.

18. Okaka JC, Okaka ANC (2001) Foods: Composition, Spoilage, Shelf-life Extension. OCJANCO Academic Publishers Enugu.

19. Mac William LD (2005) Comparative guide to nutritional supplements. Northern Dimensions Publishers, pp: 31-32.

20. Chirelli P, Brown W, Mc-Eiduff P (2000) Constipation in Australian women: Prevalence and associated factors. Int Urogynecol J 11(2): 71-78.

21. Causey JL, Feirtag JM, Gallaher DD, Tungland BC, Slavin JL (2000) Effects of dietary inulin on serum lipids, blood glucose and gastro-intestinal environment in hyper-cholesterolemic men. Nutrition Res 20(2): 191-201.

22. Okwu DE, Ndu CU (2006) Evaluation of the phytonutrients, mineral and vitamin contents of some varieties of yam (Dioscorea sp). Int J Molecul Med Advan Sci 2(2): 199-203.

23. Degras L (1993) The yam: A tropical root crop. Macmillan Press, London, pp: 490-607.

24. Gordon MN (2000) Contemporary nutrition: Issues and insights. Mc-Graw Hill Companies, New York, $4^{\text {th }}$ (Edn.), pp: 102-256.

25. Heaney RP (2000) Dietary protein and phosphorus do not affect calcium absorption. Am J Clin Nutr 72(3): 758-761.

26. Konrad M, Schlingman KP, Gudermann T (2004) Insights into the molecular nature of magnesium homeostasis. Am J Renal Physiol 286(4): F599-F605. 